\title{
SUBROGEES' STANDING TO SUE UNDER THE FEDERAL TORT CLAIMS ACT
}

WITH the passage of the Federal Tort Claims Act, ${ }^{1}$ the responsibility for determining the liability of the United States to its tort claimants was largely shifted from Congress to the federal courts.: The lawsuit has supplanted the private bill. An important class of tort claims, hovever, may continue to lie outside the jurisdiction of the federal courts: the Department of Justice has consistently maintained that the Act does not permit derivative suits by an insurer claiming subrogation to a tort action against the United States. ${ }^{3}$ The Government's position has usually been rejected on appeal: of the seven circuit courts of appeal which have considered the question, only the Fifth has denied a subrogee the right to sue." Resolution of

1. 60 STAT. $\$ 43$ (1946), as amended, 28 U.S.C. $\$ \$ 1291,1346,1402$, 1504, 2110, 2401, $2402,2411,2412,2671-80$ (1948). The provisions of the Tort Claims Aet remain substantially unchanged by the revision of the Judicial Code, effective Sent. 1, 1948, Pub. L. No. 773, 80th Cong., 2d Sess. (June 25, 1948), although all seetions vere renumbered.

Similar legislation had been enacted by the 70th Congress (H. R. 92S5) and the 76th Congress (H. R. 7236). The first bill was defeated by President Coolidge's polict veto, the second by the pressure of urgent business which foredosed Senate action. For a history of these bills and favorable recommendations for similar action, see H. R REp. No. 2245, 77th Cong., 2d Sess. 5 (1942). See also, for background material on thece early ensetments, Borchard, Government Liability in Tert, 34 YaLE L. J. 1-45, 139-43, 202-58 (1924) and Borchard, Gozernmental Responsibility in Tort-A Proposcd Stat:tory Reform, 11 A. B. A. J. 495 (1925).

2. Provision had been made previously for suits on claims arising c.r contracts, 24 StAT. 505 (1887), as amended, 23 U.S.C. $\$ \$ 91,1331-46,1348,1351,1353-7,1359,1397$, $1399,1402,1491-4,1496,1501,1503,2071,2072,2361,2401,2402,2411,2412,2501,2506$, 2509, 2510, 2511 (1948) (Tucker Act); for patent iníringement, 36 SrAr. 851 (1910), as amended, 28 U.S.C. $\$ 1498$ (1948); for admiralty and maritime torts, 41 Sr.1. 525 (1920), 46 U.S.C. $\$ 742$ (1946) ; for damages caused by a public ressel of the United States, 43 STaT. 1112 (1925), 46 U.S.C. $\$ 781$ (1946); and generally for damages non delicft, 24 STAT. 505 (1S87), as amended, $2 \$$ U.S.C. $\$ \$ 1346,2401,2402$ (1943). In the face of these enactments, it was said the "only justification" for the Gowernment's immunity from suit sounding in common law tort "seems to be historieal." SE:. Fer. No. 1400, 79th Cong., 2d Sess. 31 (1946) (recommending passage of the Tort Claims Act).

3. The Government has usually moved to dismiss suits by subrogees on the ground that the court lacks jurisdiction over the subject matter, under Fen. R. CIv. P., 12(b) (1).

4. Allowing subrogation: State Farm MIutual Liability Ins. Co. v. United States, 172 F.2d 737 (1st Cir. 1949), recersing Gray v. United States, 77 F.Supp. 869 (D.Mass. 1943); Aetna Casualty and Surety Co. v. United States, 170 F.2d 469 (2d Cir. 1943), recersing 76 F.Supp. 333 (E.D.N.Y. 1948), cert. granted, 69 S. Ct. $\$ 90$ (1949); Yorlsshire Ins. Co. v. United States, and Home Ins. Co. v. United States, 171 F.2d 374 (3d Cir. 194S), recersing Yorkshire Ins. Co. v. United States, Civil No. 10417, D.N.J., Nov. 13, 1947, and Home Ins. Co. v. United States, Civil No. 10418, D.N.J., Nov. 13, 1947, ccrt. granted, 69 S. Ct. 890, S91 (1949); United States v. South Carolina State Highway Dep't, 171 F.2d $\$ 93$ (4th Cir. 1948), affirmistg 78 F.Supp. 594 (E.D.S.C. 194S); Old Colony Ins. Co. v. United States, 168 F.2d 931 (6th Cir. 1948), rezirsing 74 F.Supp. 723 (S.D.Ohio 1947); National American Fire Ins. Co. of Omaha v. United States, 171 F.2d 206 (9th Cir. 1948), recersing Civil No. 872, S.D.Cal., Nov. 21, 1947; United States v. Chicago, R. I. \& P. Ry., 171 
this conflict is imminent, for the Supreme Court has granted certiorari in two of these cases. ${ }^{5}$

Heavily burdened by the time-consuming process of handling countless bills for private relief, Congress provided in the Act that the district courts "shall have exclusive jurisdiction of civil actions on claims against the United States, for money damages, for injury or loss of property, or personal injury or death caused by the negligent or wrongful act or omission of any employee of the government while acting within the scope of his office or employment, under circumstances where the United States, if a private person, would be liable to the claimant in accordance with the law of the place where the act or omission occurred." "Specifically excluded from this waiver of sovereign immunity are twelve types of claims, ${ }^{7}$ none of which

F.2d 377 (10th Cir. 1948). Subrogee's motion to intervene granted: Employers' Fire Ins. Co. v. United States, 167 F.2d 655 (9th Cir. 1948), reversing 74 F.Supp. 669 (S.D.Cal. 1947).

Denying Subrogation: United States v. Hill, 171 F.2d 404 (5th Cir. 1948), reversing 74 F.Supp. 129 (N.D.Tex. 1947).

5. Yorkshire Ins. Co. v. United States, and Home Ins. Co. v. United States, 171 F.2d 374 (3d Cir. 1948), cert. granted, 69 S. Ct. 890, 891 (1949).

6. 28 U.S.C. $\S 1346(b)$ (1948). As to the proper forum for suits under the Act: "Any civil action on a tort claim against the United States . . . may be prosecuted only in the judicial district where the plaintiff resides or wherein the act or omission com* plained of occurred." 28 U.S.C. $\$ 1402$ (b) (1948). This phraseology was substitutcd for the provision in the original Act that jurisdiction was laid only in those two districts. The revised provision is probably one of venue. $C f$. Hoiness v. United States, 335 U.S. 297 (1948), holding the following provisions of the Suits in Admiralty Act, 41 STAT. 525 (1920), 46 U.S.C. $\$ 742$ (1946), to relate to venue: "Such suits shall be brought in the district court of the United States for the district in which the parties so suing, or any of them, reside or have their principal place of business in the United States, or in which the vessel or cargo charged with liability is found."

7. "The provisions of . . . section 1346 (b) of this title shall not apply to-

(a) Any claim based upon an act or omission of an employee of the Government, ex* ercising due care, in the execution of a statute or regulation, whether or not such statute or regulation be valid, or based upon the exercise or performance or the failure to excrcise or perform a discretionary function or duty on the part of a federal agency or an cmployee of the Government, whether or not the discretion involved be abused.

(b) Any claim arising out of the loss, miscarriage, or negligent transmission of letters or postal matter.

(c) Any claim arising in respect of the assessment or collection of any tax or customs duty, or the detention of any goods or merchandise by any officer of customs or cxcisc or any other law-enforcement officer.

(d) Any claim for which a remedy is provided by sections 741-752, 781-790 of Title 46 , relating to claims or suits in admiralty against the United States.

(e) Any claim arising out of an act or omission of any employee of the Government in administering the provisions of sections 1-31 of Title 50, Appendix.

(f) Any claim for damages caused by the imposition or establishment of a quarantine by the United States.

(g) Any claim arising from injury to vessels, or to the cargo, crew, or passengers of vessels, while passing through the locks of the Panama Canal or while in Canal Zone waters.

(h) Any claim arising out of assault, battery, false imprisonment, false arrest, mali- 
concerns subrogation. Unwilling to reimburse insurers who have indemnified injured policyholders, the Government contends that the "strict construction" traditionally accorded statutes waiving sovereign immunity dictates non-recognition of derivative claims because they are not specifically authorized. The insurers, however, assert that they deserve recognition because their claims are not specifically barred while some others are. ${ }^{8}$ With two time-honored canons of construction meeting head on, the meaning of the Act must apparently be sought elsewhere.

The handling of derivative claims prior to the passage of the Act also provides conflicting indications of intent. On the one hand, subrogation claims exceeding $\$ 1,000$, which required a private law for relief, vere apparently disfavored by the Congressional Claims Committees and usually rejected. ${ }^{9}$ But more persuasive is the fact that derivative claims which were

cious prosecution, abuse of process, libel, slander, misrepresentation, deceit, or intercference with contract rights.

(i) Any claim for damages caused by the fiscal operations of the Treasury or by the regulation of the monetary system.

(j) Any claim arising out of the combatant activities of the military or naval forces, or the Coast Guard, during time of war.

(k) Any claim arising in a foreign country.

(l) Any claim arising from the activities of the Tennessce Valley Authority." 23 U.S.C. $\$ 2680$ (1948).

- 8. This doctrine of statutory construction-Expressio unius est cxclusio altcrius-is well recognized. See Rybolt v. Jarrett, 112 F.2d 642, 645 (Ath Cir. 1940); also 50 Ars. JUR 455 and cases there cited. In addition, Congress has satisfactorily demonstrated in the past that it can find the requisite language to bar subrogees' suits when it vants to; see the Foreign Claims Act, 55 Stat. SSO (1942), as amended, 57 Stat. 66 (1943), 31 U.S.C. \$224(d) (1946), as amended, 61 STat. 501 (1947), 31 U.S.C.A. \$224(d) (Supp. 1948) : "[I]ncluding claims of insured but excluding claims of subrogees."

9. This point, curiously enough, has not been raised by the Government. But it has been emphatically stated elsewhere:

"The Committees on Claims maintained a rule, from which they seldom deviated, refusing to compensate on subrogation claims. . . If . . the ... [tortieasor] is the government, the insuance company was unable prior to the Tort Act to recover its subrogation claim in Congress. The usual reason given for denial of such claims was that insurance companies are paid a premium for assuming risls while the government is not, and that one who undertalkes the risls for profit should be the one to bear the loss."

Anderson, Recovery from the United States Under the Federal Tort Clainis Act, 31 MIn:ti. L. REv. 456, 4645 (1947). In addition:

“. . . [i]t was the policy of Congress not to pay the claims of subrogees by private relief legislation... It will thus be seen that the position of subrogess prior to the enactment of the Federal Tort Claims Act was quite unsatisfactory."

Morris, Tort Clains Against the Unitcd Statcs, 19 Orro BAR 487, 490 (1946).

But the existence of such a "rule" or "policy" is questionable. Subrogated insurers have from time to time obtained relief: Priv. L. No. 430, 78th Cong., 2d Sess. (Dec. 6, 1944) ; Priv. L. No. 529, 77th Cong., 2d Sess. (Dec. 2, 1942) : Priv. L. No. 276, 77th Cong., $2 d$ Sess. (Feb. 16, 1942) ; Priv. L. No. 142, 77th Cong., 1st Sess. (July 30, 1941) ; Priv. I. No. 222, 76th Cong., 3d Sess. (Jan. 17, 1940). And the House Committee on Claims repudiated an anti-subrogation philosophy in one case just prior to the passage of the Tort Claims Act: 
for $\$ 1,000$ or less, and consequently eligible for initial settlement by Governmental department heads, ${ }^{10}$ were always paid by Congress whenever certified in requests for deficiency appropriations. And in these cases Congress knew it was paying subrogees. ${ }^{11}$ While this latter action may not be a conclusive indication of Congressional intent, there is nothing in the history of the Tort Claims Act to show that Congress even remotely intended to bar the holders of derivative claims from its benefits.

The Government contends, however, that considerations other than the Act itself bar actions against the United States by holders of derivative claims. To allow such suits, it argues, is to jeopardize the procedural protection afforded the United States by the Assignment of Claims Act ${ }^{12}$ and Rule 17(a) of the Federal Rules of Civil Procedure. Specifically, the Government contends that subrogation constitutes "assignment" within the meaning of the Assignment of Claims Act, which prohibits the assignment of claims against the United States, and that a subrogee to a tort claim against the United States is not a "real party in interest" within the meaning of Rule 17(a), which requires that all suits shall be prosecuted only "in the name of the real party in interest."

Both arguments appear to fail on technical as well as practical grounds. The Assignment of Claims Act has long been held to apply only to voluntary assignments, ${ }^{13}$ while subrogation is essentially assignment by operation of law. Furthermore, the purpose of the Assignment of Claims Act was not to

\footnotetext{
"In view of the fact that the fire insurance companies' right of subrogation is made a condition for the issuance of the policy, and the fact that subrogation recoverics are reflected in the rate level, this committee does not regard the fact that an insurance company collects a premium for the policy as a sound reason for excluding the insurance company from the benefits of the Military Claims Act or a sound reason for Congress to refuse to waive the sovereign immunity of the United States against proper claims."
}

H. R. Rep. No. 2655, 79th Cong., 2d Sess. 7 (1946). Since the Tort Claims Act was passed shortly after this report was made, and no further action was taken on the claim, one may infer that the committee believed recovery could be had under the Act.

10. Under the Small Tort Claims Act, 42 Sтмт. 1066, which was repealed with passagc of the present Act.

11. The propriety of derivative claims in this latter category was once questioned when the Treasury Department, upon being asked to settle an insurer's claim administrativcly, requested a ruling from the Attorney General. He replied that while the Veterans Administration and the Departments of Agriculture, Interior, and War had refused to compensate subrogees, the Post Office, Navy, and Labor Departments had settled such claims without reference to subrogation and had always obtained the necessary funds from Congress with which to pay them. Accordingly, he recommended that such claims in the future be settled up with subrogees and then certified to Congress, clearly labelled, so that "legislative action amounting to a conclusive legislative construction" might be obtained. 36 OPS. ATT'Y GEN. 553, 559 (1932). They have been paid ever since.

12. Rev. Stat. \$3447 (1908), as amended, 54 St 1 т. 1029 (1940), 31 U.S.C. \$203 (1946), as amended, 61 Star. 501 (1947), 31 U.S.C.A. § 203 (Supp. 1948).

13. Houston v. Ormes, 252 U.S. 469, 473 (1920) ; Price v. Forrest, 173 U.S. 410, 423-5 (1899) ; Goodman v. Niblack, 102 U.S. 556, 560 (1880) ; Erwin v. United States, 97 U.S. 392, 397 (1878). 3 Moore, Federal Practice 1337 n.7 (2d ed. 1948). 
limit the liability of the United States-a purpose for which the Government would invoke it here ${ }^{1.9}$ - but rather to make it easy for the United States to assert counterclaims and set-offs against an original claimant. These rights of the United States as a defendant are partially secured by Rule 17(a), and wholly secured by the Tort Claims Act itself, for the jurisdiction which it grants to hear claims also includes jurisdiction over counterclaims and setoffs which the Government wishes to raise against any party plaintiff suing under the Act. ${ }^{15}$

The Government's argument on Rule 17(a) seems to be that a subrogee should not be permitted to sue because the United States might thereby be forced, contrary to the provisions of the Tort Claims Act, to appear in court twice on the same cause of action, either to defend a subsequent suit by the subrogor, or to assert a counterclaim or set-off against him. But none of these difficulties need arise if Rule 17(a) is properly construed. If the insurer is a full subrogee, he is the only real party in interest, and a suit by the subrogor should be dismissed. ${ }^{16}$ In the case of partial subrogation insured and insurer are both real parties in interest ${ }^{17}$ and either may sue. ${ }^{15}$ On the Gov-

14. A similar attempt to limit the liability of the United States was made in Price v. Forrest, note 13 supra, where the Government tried unsuccessfully to bar the prosecution of a claim against the United States by a receiver to whom a court with proper jurisdiction had ordered that the claim be assigned.

15. "The jurisdiction conferred by this section [1346(b)] includes jurisdiction of any set-off, counterclaim, or other claim or demand whatever on the part of the Cnitcd States against any plaintiff commencing an action under this sectioun." 2S U.S.C. \& 1316 (c) (1948). As to the right of an obligor to counterclaim or set-off against an assignee, see generally Restatenrent, Contracts $\$ 167$ (1932).

16. See, on subrogation aspects, CLARk, LaW of Code Plesorsig $\$ 24$ (2d ed. 1947) and 3 Moore, Federal Practice 1346-51 (2d ed. 1948). Briefly, the purgose of the "real party in interest" provision is to force prosecution in the name of the party having the substantive right to be enforced. CLARE, $\$ 22 ; 3$ MICoRE, at 1305. Where the insured has been fully compensated for his loss, he has no such right; it has passed to the insurer.

It is assumed in this Note that subrogation is part of the substantive law of the state where the actionable wrong was committed. If this were not so, the United States would seem to be immune from suits by subrogees simply because the Tort Claims Act provides for federal liability only "[u]nder circumstances where the United States, if a private person, would be liable to the claimant. . ." 2 S U.S.C. $\$ 1346$ (b) (194\$). If, however, state law should permit the insurer to sue, but only in the name of the injured party-a construction of the "real party in interest" code provision which Professor Mloore and Judge Clark believe to be erroneous-there would seem to be nothing to bar him from suing in his owor name in the federal courts, particularly where the right to be enforeed is a federal one. This in no way affects the right to subrogation, which is part of the substantive, not adjective law; it merely requires that suit be brougit in the name of the party entitled to keep the proceeds. The Government has at least partially conceded the validity of this argument: "While the question of whether an actionable wrong has occurred is controlled by state law, the question as to whose name the action must be filed in is procedural and must be determined by the law of the forum." Supplemental Brief of Appellant, p. 8, United States v. South Carolina State Highway Dep't, 171 F.2d $\$ 93$ (4th Cir. 1948).

17. The insurer to the extent of indemnification; the injured party to the estent that he remains unreimbursed.

18. Williams v. Powers, 2 Fed. Rules Dec. 362 (N.D.Ohio 1941); 3 Mlouse, Feuzar 
ernment's motion, however, either party as individual plaintiff may be compelled to join the other to prevent dismissal of the suit. ${ }^{19}$ Thus the United States could suffer no procedural disadvantages, except in the peculiar situation where it wished to assert a counterclaim or set-off greater than the amount recoverable in the main action and the injured party could not be joined in that action on a partial subrogation theory. ${ }^{20}$ In such case, the injured party should be denominated an indispensable party plaintiff, and his presence before the court required if the action is to proceed."2 Hence the United States should always be able fully to adjudicate its rights in one action.

Practice 1348 (2d ed. 1948). Should the injured party sue, however, the insurer may intervene. Employers' Fire Ins. Co. v. United States, 167 F.2d 655 (9th Cir. 1948); Williams v. Powers, supra. FED. R. CIv. P., 24.

19. State Farm Mutual Liability Ins. Co. v. United States, 172 F.2d 737, 739 (1st Cir. 1949) ; 3 Moore, Federal Practice 1348, 44-5 (2d ed. 1948). Fed. R. Civ. P., 19(a). And the Government need not worry about how the joinder is accomplished: it is the subrogee's business to choose the proper forum initially and to produce the injured party if his presence be required. Should the injured party in such a case be uncooperative, the insurer might possibly make him a defendant or an involuntary plaintiff. For a discussion of these procedural devices, see 3 Moore, Federar Practice 2144-55 (2d ed. 1948).

20. If the counterclaim were less than the original claim, only the difference would be recoverable and the presence of the insured unnecessary. But it is possible that the subrogee's right of action might be defeated entirely and no part of the counterclaim paid in the principal action. The Government would then be forced to sue the injured party in a second action, which would deprive the first forum of its jurisdiction over counterclaims arising from the original suit and thereby conflict with the expressed provisions of the Act. The problem was first mentioned in Aetna Casualty \& Surety Co. v. United States, 170 F.2d 469 (2d Cir. 1948), where Judge Frank, speaking for the court, found tho "favored situation of the government" with respect to counterclaims to conflict with "the reiterated requirement that we should treat the United States like a private individual. ..." In adopting the latter as "more fundamental," the court said, "We think . . . the Congress did not intend to limit the jurisdiction of the district courts more that it is limited by the specific exceptions." Id. at 472 . But the counterclaim was not an issue in the case except as the court made it orie; on that ground Judge Learned Hand, concurring: in part, refused to rule on the point. And there are alternatives to the court's solution: see text accompanying note 21 infra.

In any case, while the discussion of counterclaims may be merited, it seems extremely unlikely that the Government will ever have a set-off to assert against a subrogatcd plaintiff-insurer. To that extent, imaginary horribles which may result if a set-off docs arise should probably not weigh heavily in construing the Act for the vast majority of cascs.

21. The indispensable party concept is flexible. The general rule appears to be that "[h] is presence is required in order that the court may make an adjudication cquitable to all persons involved." 3 Moore, Federai Practice 2145 (2d ed. 1948). If it must be assumed, as has here been assumed throughout, that the Government must never be forced to litigate a cause of action twice even though a private party might have to under similar circumstances, then the injured party must under the conditions described in the text be denominated an indispensable party simply because the Tort Claims Act requires it. This solution does not tamper with accepted notions as to parties, and scems reasonable here because the Government's alternative theory goes out of its way to create a conflict between the Act and the Federal Rules.

22. "Of course, if indispensable parties are not and cannot be joined, the court cannot 
Aside from procedural objections to the recognition of derivative claims, it has been argued that permitting an insurer to recover on a federal tort claim would in effect be giving the insurer a windfall, since a premium has been received for bearing the risk of the loss for which it seels recovery:.33 But this theory in turn is based upon the dual assumption that insurance rates are not geared to allow for recovery from a tortfeasor, and that an insurer would treat the amount recovered as "profit" rather than reduce insurance rates accordingly. If the assumption is true, the argument should be directed against faulty rate structures, ${ }^{24}$ not the principle of subrogation. Taxpayers, not policyholders, should bear financial losses occasioned by Government tortfeasance.

Whatever the technical and policy arguments involved, upholding the Government's position would seem to do little more than force insurers to redraft their policies to protect themselves. Two means have been pointed out whereby they could effect recovery even if they could not sue for themselves: payment to the insured could be made contingent upon his suing the United States, or the insurer could make the indemnification as a loan and subsequently sue the United States in the name of the insured.5 There is no readily apparent reason for encouraging such devices by disallowing derivative claims.

For a statute waiving sovereign immunity, the phraseology of the Tort Claims Act is unusually comprehensive in setting out the liability of the United States as identical to that of a private party. To defeat this broad assumption of liability, the Government has mustered an ancient canon of construction easily counterbalanced by another of equal applicability, and a trio of technical and public policy arguments which appear clearly unsound.

Not only does it seem proper to include subrogation claims within the scope of the Act as a matter of statutory interpretation; in terms of practical

proceed; it cannot enter an equitable judgment in the cause." 3 MIoose, Fruenal Practice 2205 ( $2 \mathrm{~d}$ ed. 1948). Again it is the subrogec's problem to produce the injured party. Ses note 19 supra. As a practical matter, insurers would probably malse the injured party sue to recover on his policy if he were unwilling to assist them in prosecuting the tortieasor to recover back the loss.

23. See note 9 supra.

24. As a result of the decision in United States v. South-Eastern Undervriters Association, 322 U.S. 533 (1944), which held insurance to be interstate commerce, tite Federal Government is now in a position to attack such faulty rate structures if and where they exist. Indeed, subsequent Congressional enactments demand state action if federal regulation of insurers is to be avoided. 59 Star. 33 (1945), 15 U.S.C. \& 1011 (1946); 59 St.AT. 34 (1945), 15 U.S.C. \$1012 (1946), as amended, 61 Srar. 443 (1947), 15 U.S.C.A. 1012 (Supp. 1948).

25. Bryan, J., in Ins. Co. of North America v. United States, 76 F.Supp. 951, 953 (D.Va. 1948). The making of such a loan, even when receipted, has no effect on the injured party's right to sue. Augusta Broadcasting Co. v. United States, 170 F.2d 199 (5th Cir. 1948). An analogy may be drawn between these devices and those employed by insurers of railroad shippers to protect themselves from losses occasioned by carrier negligence toward goods in transit. See Campbell, Non-Consensual Surctyship, 45 Yaut L. J. 69, 83-4 (1935). 